\title{
Can Thermal Water Be an Alternative Treatment Method for Wound Healing?
}

\author{
Mustafa Ersöz (Corresponding author) \\ Dept. of Orthodontics \\ Ortadoğu Hospital, İvedik Cad no:55 Yenimahalle-ANKARA, Türkiye \\ Tel: 90-530-343-8096 E-mail: mustafaersz@yahoo.com

\begin{abstract}
Ahmet Koç
Adres:Baran Elektrik A.Ş. İncesu Cad.No:12 Kolej / ANKARA

Dept. of Medical Pathology, Selçuk University

Şemsi Tebrizi Mah. Ankara Cad. No:6,42030 Konya, Türkiye
\end{abstract}

Tel: 90-334-241-0041 E-mail:akoc68@hotmail.com

\author{
Pelin Acar Ulutaş \\ Dept. of Orthodontics, Inonu University \\ Merkez Kampüsü, 44280, Malatya, Türkiye,
}

Tel: 90-422-377-30 00 E-mail:acarpelin88@gmail.com

Ferhan Şerefoğlu

Biolog, İşletme müdürü. Adres: Feribot İskelesi Yanı Pertek Thermal, Pertek, Tunceli, Türkiye,

Tel: 90-533-281-6884 E-mail: ferhanserefoglu@ hotmail.com

Received: March 6, 2017 Accepted: April 17, 2017 Published: May 25, 2017

doi:10.5296/jbls.v8i2.10865 URL: https://doi.org/10.5296/jbls.v8i2.10865 


\section{Abstract}

The research is carried out to determine the effect of thermal water on wound healing. The research is carried out on twenty experimental rats. The rats are divided into two groups as control group (10 units) and study (10 units) group. Both groups were worked synchronous. The study (10 units) group was treated with thermal water and it was provided to contact with water of the wound surfaces. Control group was fed with normal water. As a result of the research, it was revealed that there are differences between two groups in histological and observational surveys. The findings that are obtained were analyzed statistically. It was observed that is statistically significant wound healing differences between the groups. According to the results and observations, it can be said that this thermal water is an effective role in wound healing.

Keywords: Thermal Water, Alternative Treatment Method, Wound Healing

\section{Introduction}

The human body plays a crucial role in maintaining healthy skin integrity in the maintenance of physiological homeostasis (Sorg et al., 2017). However, acute or chronic traumas, diseases, some infections and surgical operations that can occur for many reasons can lead to deterioration of the integrity of the skin tissue and injuries (Petersen et al., 2016).There are three types of wound form and the healing takes place in three phases. These are primary, secondary and tertiary healing (Brandi et al., 2004).Primer healing; occurs when the sides of the wound are brought together with sutures, staples or tape, and minimal scarring occurs in the wound area. Secondary healing is caused by contraction, granulation and epithelization of the open wound anda larger scaris formed when compared with primary healing (Diji, 1959 and Voisin et al., 2010). In the secondary and pirimer wound healing, the wound repair process takes place regularly and in certain stages (Yang et al., 2011). While anatomical and functional integrity is better acquired in acute injuries, repair in chronic injuries is not regular. Chronic wound occurs if wound closure can not occur (Ye et al., 2008). Since there is no wound integrity in chronic wounds, adequate anatomical and functional correction is difficult or is not possible (Irie et al., 2005). There are many studies on wound treatment and wound healing. While most of these studies are within the scope of medical treatment, it is seen that there are attempts to find solutions in diseases and treatments where complimentary treatments studies are carried out in hydrotherapy with spa water (Nayak \& Pinto Pereira, 2006). Although the wound and healing mechanism is generally known, The effect of complementary treatments and spas on wound healing and the treatment mechanism is still a research topic. The physiological and teratogenic effects of thermal $\mathrm{CO} 2$ therapy are used in central and eastern Europe (Fabry et al., 1995) and are used as adjunctive therapy in the treatment of many diseases.It is stated that therapies made with hot spring water are beneficial in Hypertension, vascular occlusion, various arterial blood flow disorders, microcirculatory disorders, delayed wound healing and certain cardiac diseases (Fabry et al., 1995 and Sato et al., 2009). Thermal waters may be beneficial with mineral contents (Dandinoğlu et al., 2016), have effects on oxidant - antioxidant systems and may be immunosuppressive (Fioravanti et al., 2011). The water temperature and the $\mathrm{CO} 2$ gas in the 


\section{Al Macrothink}

skin increased vasodilatation and new vessel formation and increased the blood circulation and tissue perfusion in the areas where CO2 gas was applied (Irie et al., 2005).

Factors affecting wound healing include; Systemic problems such as age, anemia, corticosteroids, cytotoxic drugs, malnutrition, obesity, malign diseases, infection, vitamin deficiencies and genetics as well as local factors such as blood flow, denervation, hematoma, surgical technique and suture material (Ozerdem et al., 2001). However, it can be seen that in many chronic diseases such as diabetes mellutus, peripheral vascular disease (Sorg et al., 2017) and in many cases requiring intervention for wound healing; the medical approach is inadequate. Today, it is known that patients who are desperate in situations where medical treatment is inadequate are seeking remedy with complementary treatments including spas. In this context; those, who have some diseases in which medical treatment is inadequate, have used spa for the treatment of wound as a complementary treatment. In addition, it is seen that wounds did not replicate for along time (1-2 years, figure 4,5,8).

In our study, the effect of the thermal waters containing $\mathrm{CO} 2$ and various minerals on the wound healing was investigated in the wound model formed in rats with the above-mentioned findings.

\section{Material and Method}

Prior to commencing work, approval was taken from Inonu University Medical Faculty Experimental Animal Research Ethics Board with date/number (2016/A-20). A total of 20 male Sprague-Dawley rats weighing 300-350 gr were used in the study. The rats were divided into two groups as Control and Experiment group. For 12 days following the surgery, our health ministry provided spa water that is permissible as drinking water was given to rats in study group $(n=10)$. In addition, the wound surfaces were kept in contact with the thermal water in the water bath, 2 times a day for 30 minutes in the first 5 days and 2 times a day for 45 minutes in the following days. In the control group $(n=10)$, wound healing was followed without any treatment for 12 days after surgery (Normal water was given as drinking water). During the study, rats were fed in single cages, fed with standard rat diet and follow-ups were made.

For wound formation, anesthesia was achieved in rats with intraperitoneal $90 \mathrm{mg} / \mathrm{kg}$ ketamine and 10mg / kg xylazine injection and rat's back region was shaved. On the midline and $2 \mathrm{~cm}$ in length, skin-subcutaneous full-thickness skin lesion and wound defect were formed (Figure 1). Both groups were sacrificed by intraperitoneal administration of high-dose sodium pentothal at 12 th day. 


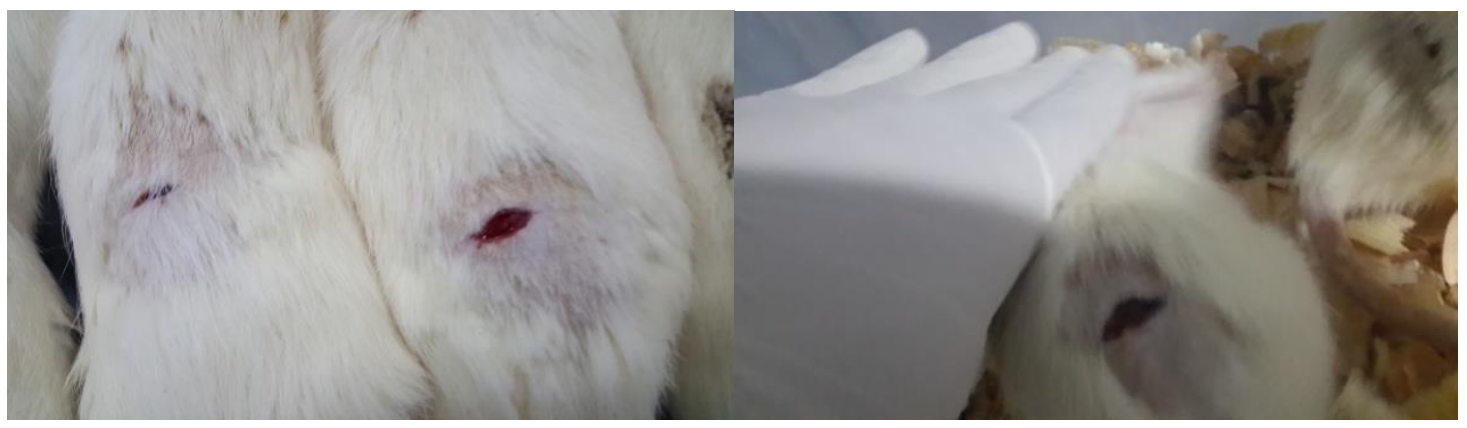

Figure 1. Wounds with cutaneous and subcutaneous incisions

\section{Method}

For histological examination, $4 \times 4 \mathrm{~cm}$ skin islands were excised in the center of the back of the rats. For light microscopic examination, fixing was first performed in a $10 \%$ Neutral Buffer formaldehyde solution. After fixation, tissue samples were placed in trays and washed under water for 24 hours. For water removal; tissues were passed through the alcohol series at an increasing rate. Subsequently, the tissues were transferred to xylene for the purpose of polishing and then immersed in molten paraffin. Hematoxylin-Eosin staining method was applied to the sections of 4 micron thickness obtained from the prepared paraffin blocks for all groups. The sections were evaluated in CARL ZEISS brand AXIOM SCOPE (Germany) computer-aided imaging system and pictures were taken. As a result of evaluations made with hematoxylin-eosin staining; wound healing score evaluation criteria table was prepared. IBM SPSS statistical 24.0 program was used in the data and statistical analyzes. Statistical evaluations were performed using the Mann-Whitney $U$ test for wound healing scoring criteria and the exact (Pearson's exact) Pearson Chi-Square test for qualitative data comparison. $\mathrm{P}<0.05$ was considered significant $(\mathrm{P}<0.05)$.

Control and study (spa group) groups were compared in terms of field measurements, mean recovery percentages and wound healing parameters (in terms of collagen accumulation, amount of inflammatory cells, amount of granulation, accumulation of collagen, re-epithelization, angiogenesis, and ulcer formation). These parameters were scored according to the wound healing score evaluation criteria (Table 1) and statistical analysis were made.

Table 1. Wound healing score evaluation criterias

\begin{tabular}{|c|c|c|c|c|c|c|}
\hline Score & Reepithelialisation & Granulation & $\begin{array}{l}\text { Accumulation } \\
\text { of collagen }\end{array}$ & $\begin{array}{l}\text { Inflammatory } \\
\text { cells }\end{array}$ & Angiogenesis & $\begin{array}{l}\text { Ulcer } \\
\text { formation }\end{array}$ \\
\hline 0 & Absent & $\begin{array}{l}\text { Absent } \\
\text { immature }\end{array}$ & Absent & Absent & Absent & $\begin{array}{l}\text { Extensive } \\
\text { and deep, } \\
\text { abscess }\end{array}$ \\
\hline 1 & Scanty & Scanty & Minimal & Few & Blood & Extensive \\
\hline
\end{tabular}




\begin{tabular}{|c|c|c|c|c|c|c|}
\hline & & & & & $\begin{array}{l}\text { capillaries less } \\
5\end{array}$ & \\
\hline 2 & $\begin{array}{l}\text { Moderate } \\
\text { immature or thin }\end{array}$ & Moderate & Moderate & Moderate & $\begin{array}{l}6-10 \text { blood } \\
\text { capillaries }\end{array}$ & $\begin{array}{l}\text { Absent or } \\
\text { small }\end{array}$ \\
\hline 3 & Profound & Mature & Profound & Profound & $\begin{array}{l}\text { Blood } \\
\text { capillaries } \\
\text { more than } 10\end{array}$ & Absent \\
\hline
\end{tabular}

\section{Results}

During the study period, 3 rats in the control group died within the first 5 days. It was found that $\mathrm{CO} 2$ was deposited immediately on the water and no deaths were observed in the rats after removal of $\mathrm{CO} 2$ on the water by special propellers. On day 12, all of the rats in the study group were treated for wound healing and wound openings were closed (Figure 2), whereas in the control group, wound healing was observed at specific level but wound openings were not closed (Figure 3) and rats in both groups were sacrificed on Day 12.

Note: All photos (Figure 2-8) that have used in the research below has taken by us, by using own machine.

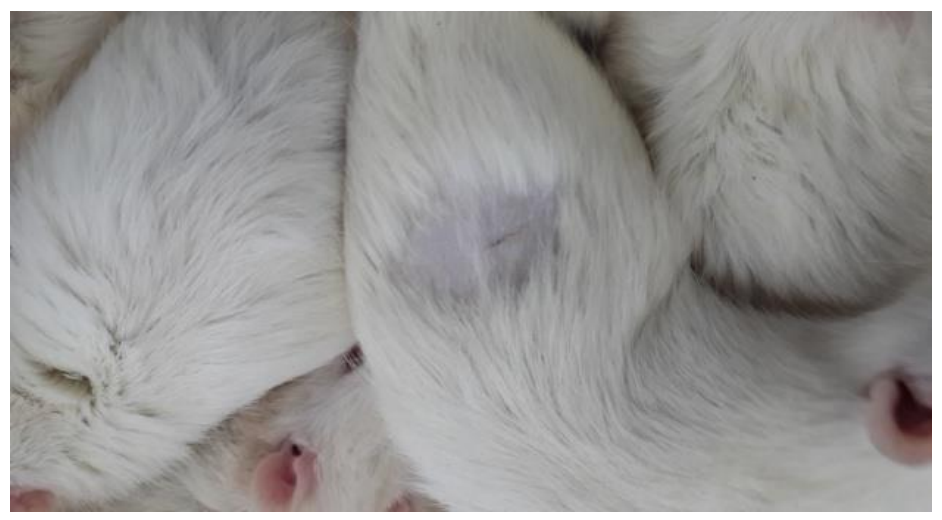

Figure 2. The wound was epithelised in experimental group on day 12 


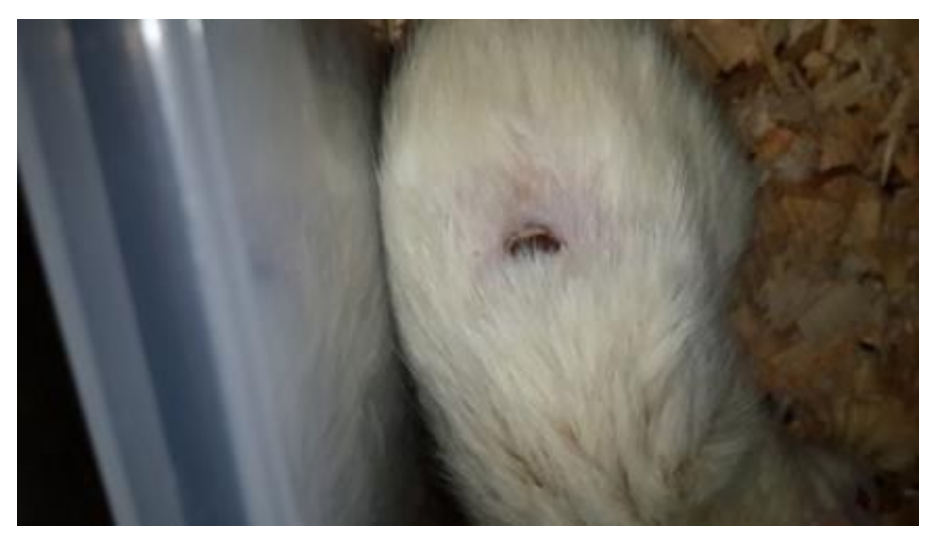

Figure 3. The wound was unhealed completely in control group on day 12
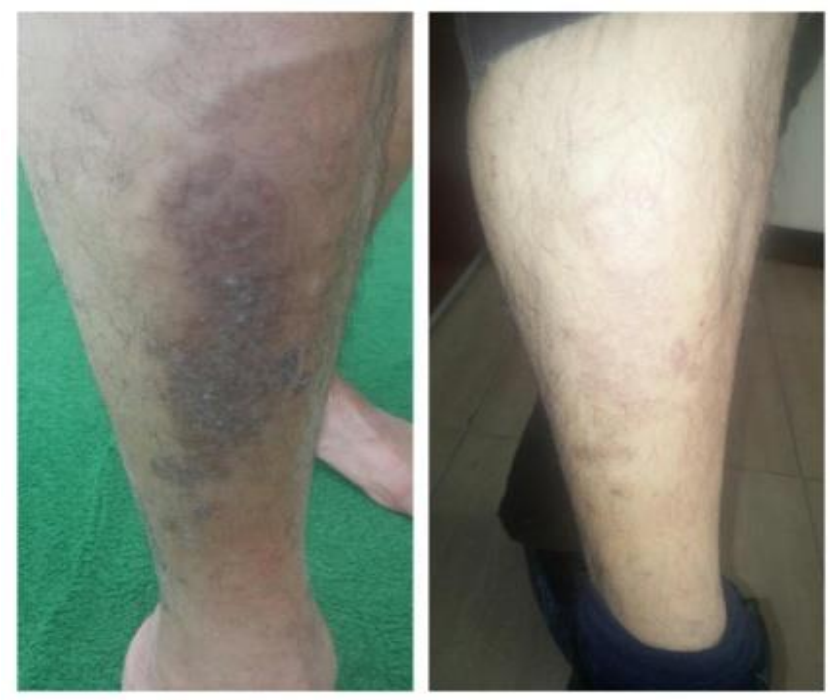

Figure 4. Healing of Neuraldermatitis on day 28
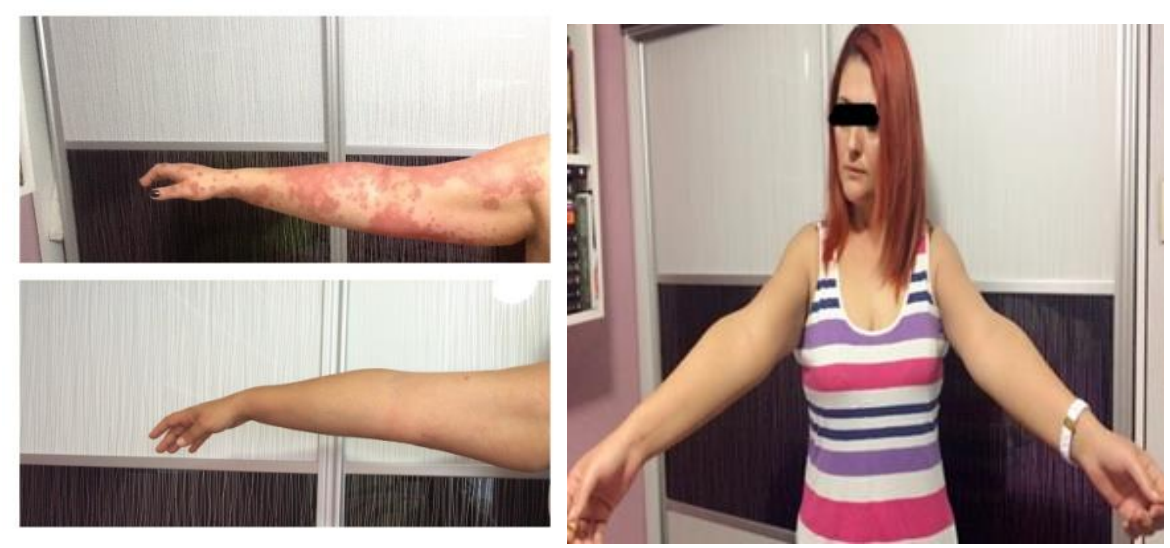

Figure 5. Healing of Psoriasis healing on day 14 and on month 24 


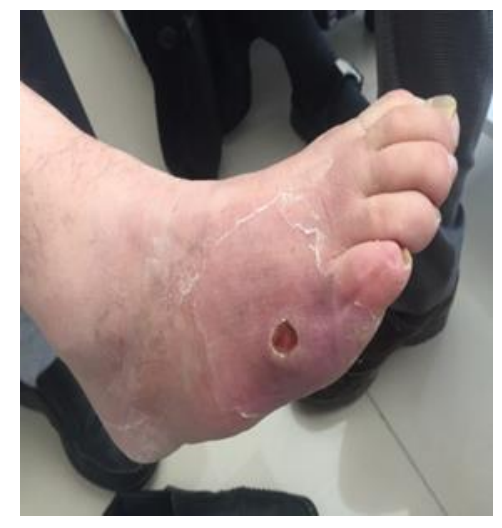

Figure 6. Diabetic foot ulcer
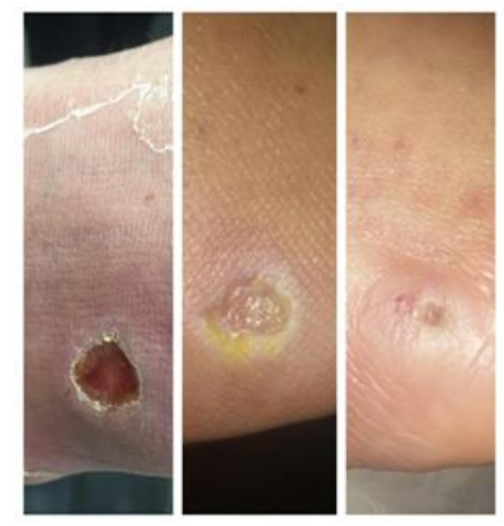

Figure 7.Healing of diabetic

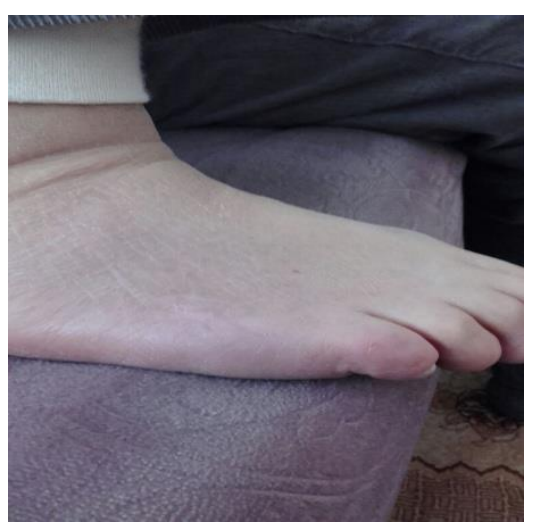

Figure 8.Healing of diabetic ulser on day 8 and 24 ulser on month 14

These figures showed that results of thermal water theraphy of unhealed neuraldermatitis about 22 years with medical treatment, recurrent psoriasis and unhealed diabetic foot ulcer about 3 years.

The numerical and percent histological parameter of each group were tabulated in table 2-7. 


\section{Macrothink

Table 2. Comparison of reepithelialisation between in the groups on day 12

\begin{tabular}{|c|c|c|c|c|}
\hline Score & $\begin{array}{c}\text { Study group } \\
(n=7)\end{array}$ & \multicolumn{2}{c|}{ Control group (n=10) } \\
\hline 0 & 1 & $14.2 \%$ & 2 & $20 \%$ \\
\hline 1 & 0 & $0 \%$ & 4 & $40 \%$ \\
\hline 2 & 2 & $28.5 \%$ & 3 & $30 \%$ \\
\hline 3 & 4 & $57.1 \%$ & 1 & $10 \%$ \\
\hline$p$ & \multicolumn{3}{|c|}{0,051} \\
\hline
\end{tabular}

The starting of epithelization was observed in the received tissues out of one rat. It was seen that only one rat's wound started epithelization in the control group. The epithelization did not starton the other rats.

Table 3. Comparison of amount of granulation tissue between in the groups on day 12

\begin{tabular}{|c|c|c|l|l|}
\hline Score & \multicolumn{2}{|c|}{$\begin{array}{r}\text { Study group } \\
(n=7)\end{array}$} & \multicolumn{2}{l|}{ Control group (n=10) } \\
\hline 0 & 3 & $42.8 \%$ & 0 & $0 \%$ \\
\hline 1 & 1 & $14.2 \%$ & 1 & $10 \%$ \\
\hline 2 & 2 & $28.5 \%$ & 5 & $50 \%$ \\
\hline 3 & 1 & $14.2 \%$ & 4 & $40 \%$ \\
\hline$p$ & \multicolumn{3}{|c|}{0,047} \\
\hline
\end{tabular}

Mature and medium degree mature granulation tissue was observed in all ratsin the control group, whereas mature granulation tissues were found in only one rat in the study group. There was a significant difference between granulation levels in the control and study groups. 


\section{Macrothink}

Table 4. Comparison of amount of collagen accumulation between in the groups on day 12

\begin{tabular}{|c|l|l|l|l|}
\hline Score & \multicolumn{2}{|c|}{$\begin{array}{r}\text { Study group } \\
(n=7)\end{array}$} & \multicolumn{2}{l|}{ Control group (n=10) } \\
\hline 0 & 1 & $14.2 \%$ & 5 & $50 \%$ \\
\hline 1 & 1 & $14.2 \%$ & 3 & $30 \%$ \\
\hline 2 & 2 & $28.5 \%$ & 2 & $20 \%$ \\
\hline 3 & 3 & $42.8 \%$ & 0 & $0 \%$ \\
\hline$p$ & \multicolumn{3}{|c|}{0,028} \\
\hline
\end{tabular}

The collagen accumulation at the wound site of the treated rats was different according to the control group ( $\mathrm{p}<0.05)$. It was seen that a medium degree and moderate amount of collagen accumulation in five rats, in the study group on the 12th day, whereas in the control group, it was observed that accumulation of collagen in five rats did not start. According to this finding, there was a significant difference between two groups ( $\mathrm{p}<0.05)$.

Table 5. Comparison of amount of inflamattory infiltrate between in the groups on day 12

\begin{tabular}{|c|l|l|l|l|}
\hline Score & \multicolumn{2}{|c|}{$\begin{array}{c}\text { Study group } \\
(n=7)\end{array}$} & \multicolumn{2}{|c|}{ Control group (n=10) } \\
\hline 0 & 3 & $42.8 \%$ & 0 & $0 \%$ \\
\hline 1 & 2 & $28.5 \%$ & 0 & $0 \%$ \\
\hline 2 & 1 & $14.2 \%$ & 4 & $40 \%$ \\
\hline 3 & 1 & $14.2 \%$ & 6 & $60 \%$ \\
\hline$p$ & \multicolumn{5}{|c|}{0,027} \\
\hline
\end{tabular}

The accumulation of inflammatory cells was rather lowin the group treated for 12 days. For it was not complete of the wound healing process in the control group, abundant amounts of inflammatory cells were detected. There was a statistically significant difference between the two groups when evaluated between themselves. 
Table 6. Comparison of angiogenesis between in the groups on day 12

\begin{tabular}{|c|l|l|l|l|}
\hline Score & \multicolumn{2}{|c|}{$\begin{array}{c}\text { Study group } \\
(n=7)\end{array}$} & \multicolumn{2}{|c|}{ Control group (n=10) } \\
\hline 0 & 0 & $0 \%$ & 0 & $0 \%$ \\
\hline 1 & 3 & $42.8 \%$ & 0 & $0 \%$ \\
\hline 2 & 3 & $42.8 \%$ & 4 & $40 \%$ \\
\hline 3 & 1 & $14.2 \%$ & 6 & $60 \%$ \\
\hline$p$ & \multicolumn{5}{|c|}{0,021} \\
\hline
\end{tabular}

According to angiogenesis table, it had seen less than 10 new blood vessels in the study group. It had also found more than 10 new blood vessels in the control group. According to these findings, there was a statistically significant difference in both groups.

Table 7. Comparison of the ulseration scores between in the groups on day 12

\begin{tabular}{|c|l|l|l|l|}
\hline Score & $\begin{array}{c}\text { Study group } \\
(n=7)\end{array}$ & \multicolumn{2}{l|}{ Control group (n=10) } \\
\hline 0 & 0 & $0 \%$ & 0 & $0 \%$ \\
\hline 1 & 0 & $0 \%$ & 3 & $30 \%$ \\
\hline 2 & 1 & $14.2 \%$ & 3 & $30 \%$ \\
\hline 3 & 6 & $85.7 \%$ & 4 & $40 \%$ \\
\hline$p$ & \multicolumn{3}{|c|}{0,099} \\
\hline
\end{tabular}

Ulcers were observed as very small area in only one rat in the study group for twelve days whereas, ulceration were observed in six rats in the control group. There was not a significant difference between group ulceration on the twelfth day in the study and control group but, it can be said that, there is a proportional difference between two groups.

However, when the wound healing parameters were evaluated numerically and proportionally (Table 2-7); It was seen that when compared with the control group, the wound healing of the rats in the study group was better with larger differences in proportion.

According to wound healing scores; it was found that there was a statistically significant difference in the 5 recovery parameters (reepithelialisation, collagen accumulation, granulation tissue, inflammatory cell volume and angiogenesis) between the study group and the control group and the efficacy of wound healing was increased in the study group. In the 


\section{Macrothink}

other wound healing parameter (ulcer), no statistically significant difference was observed between the groups.

Histological and imminohistochemical findings of the parameters indicating the healing process of each group were revealed by photographs (figures, 9-14).

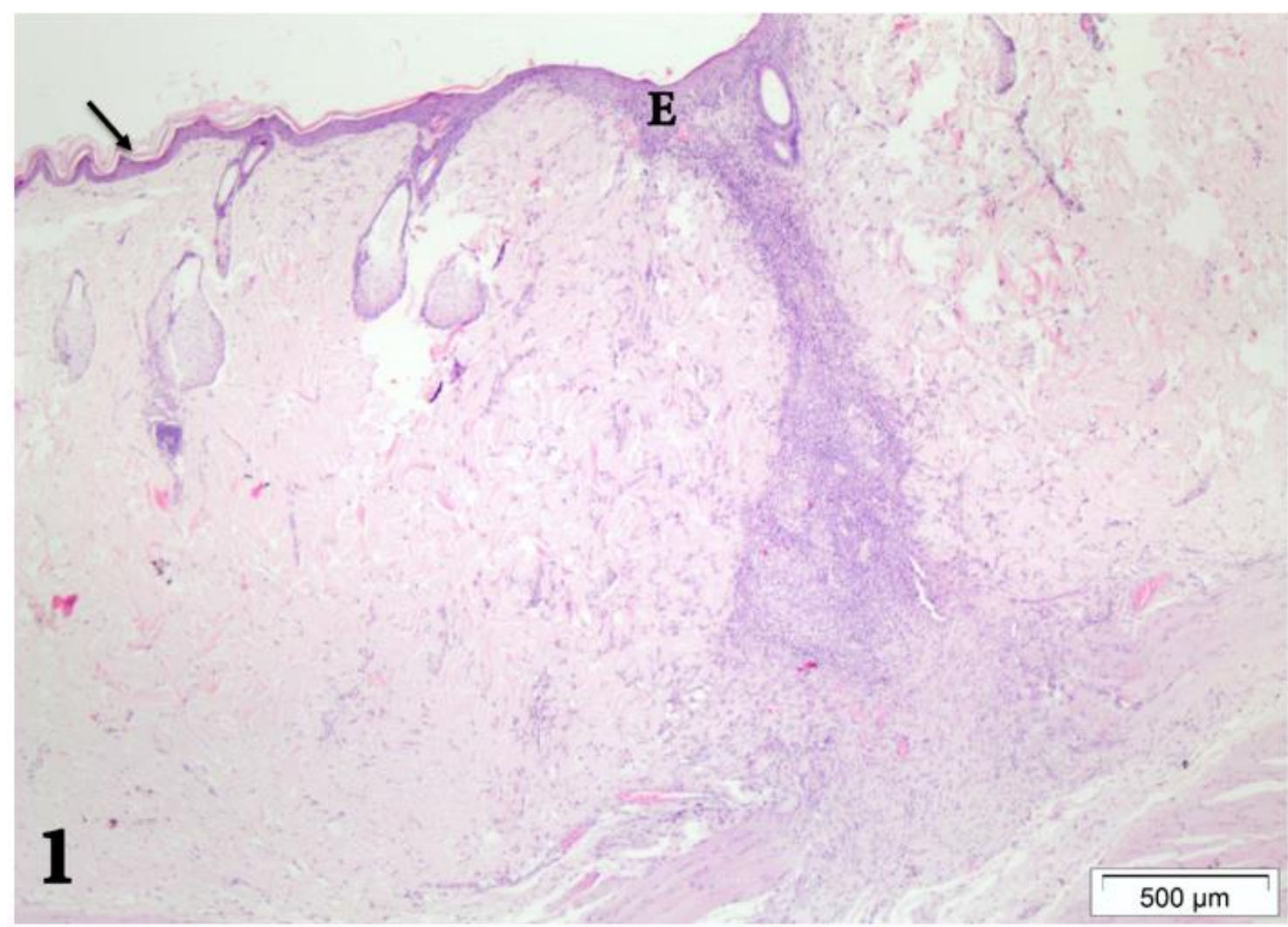

Figure 9. Study Group, Arrow: Completed wound of reepithelialisation E:Epithelial layer 


\section{MInstitute Macrothink}

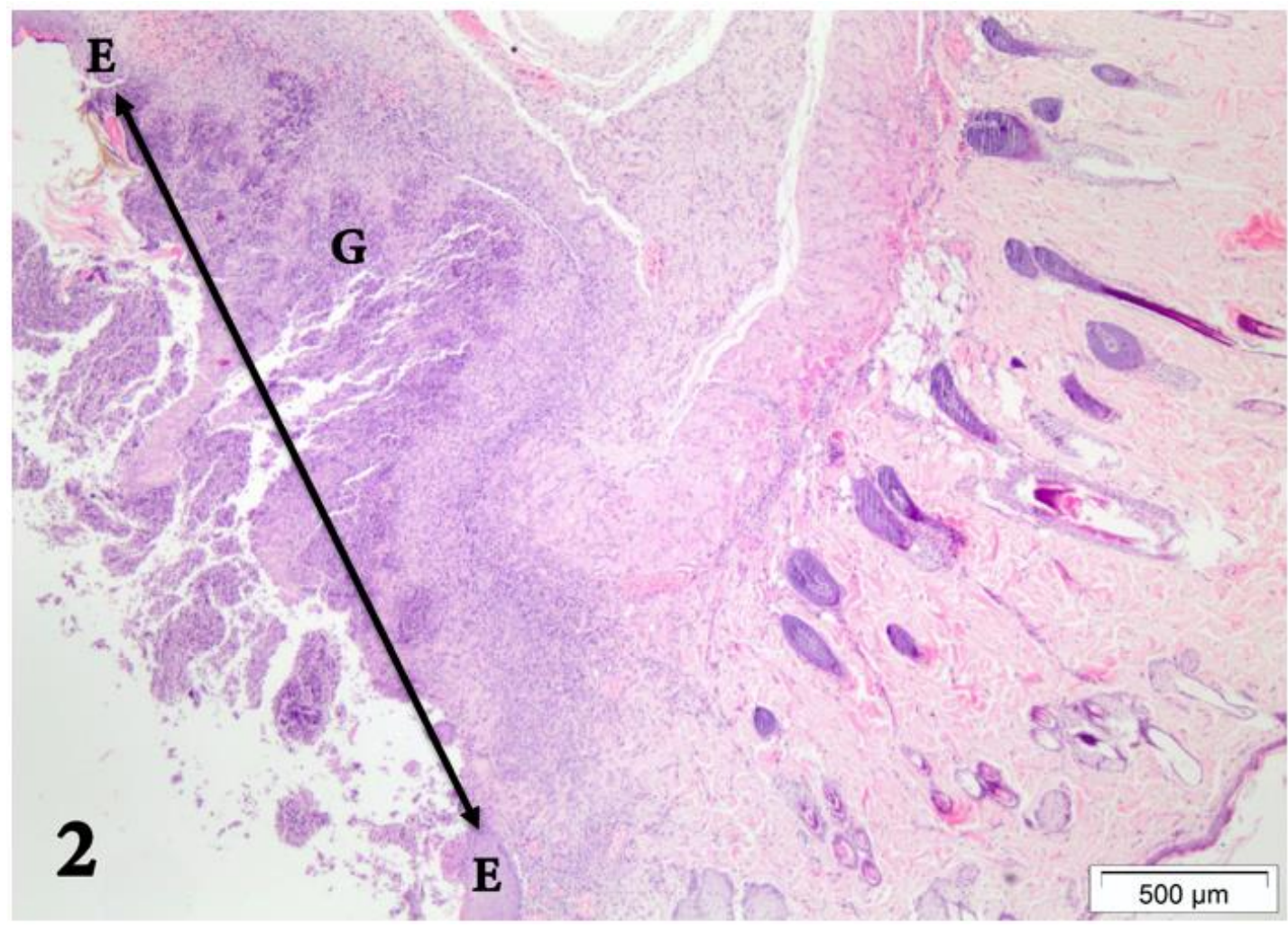

Figure 10. Control Group, Uncompleted wound of reepithelialisation E:Epithelial layer, G: granulation tissue, E Arrow with two head E : Wound Lips

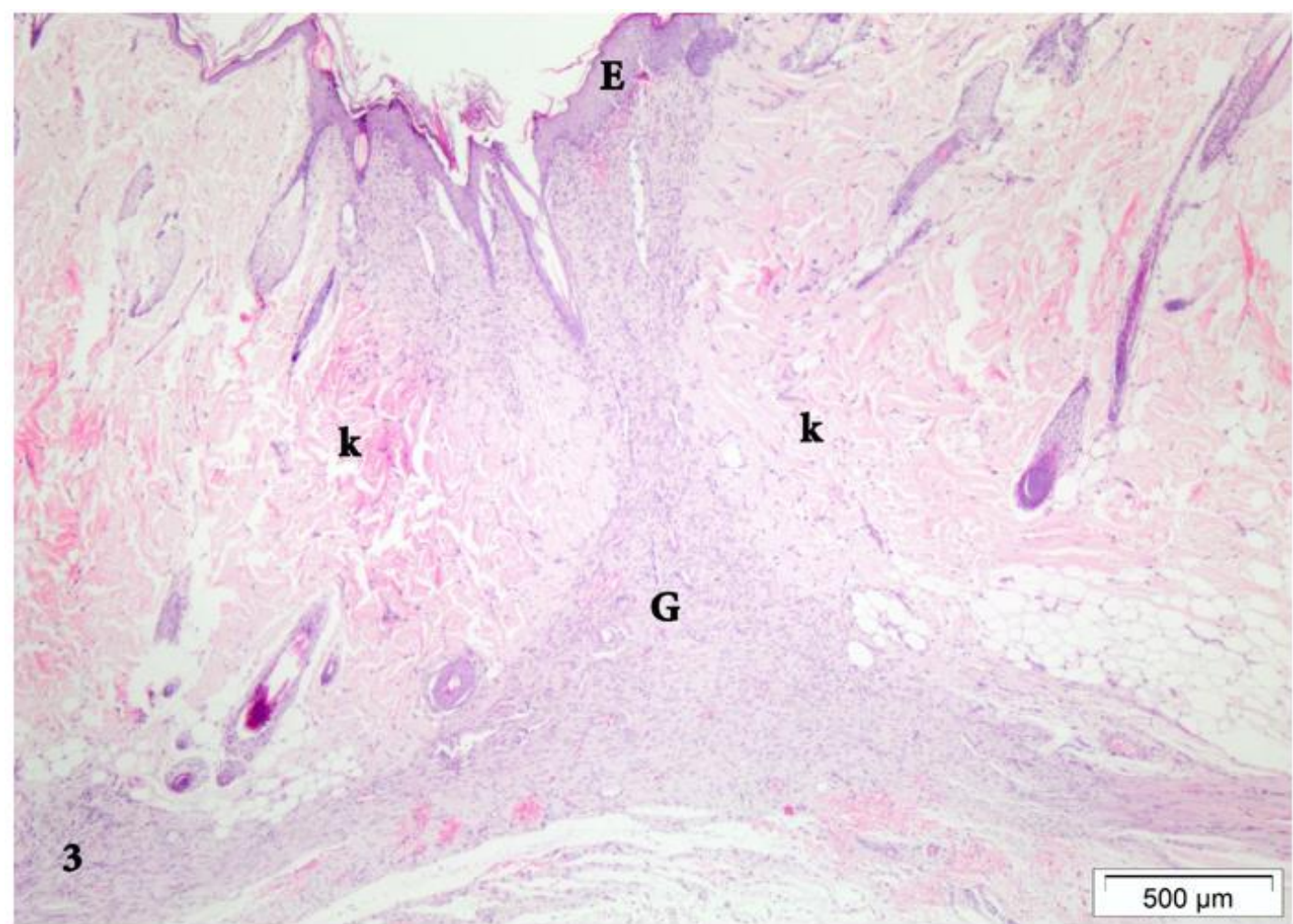

Figure 11. Study Group, Collagen Accumulation and Granulation Tissue. E: Epithelial, k:Collagen G:Granulation tissue 


\section{Macrothink}

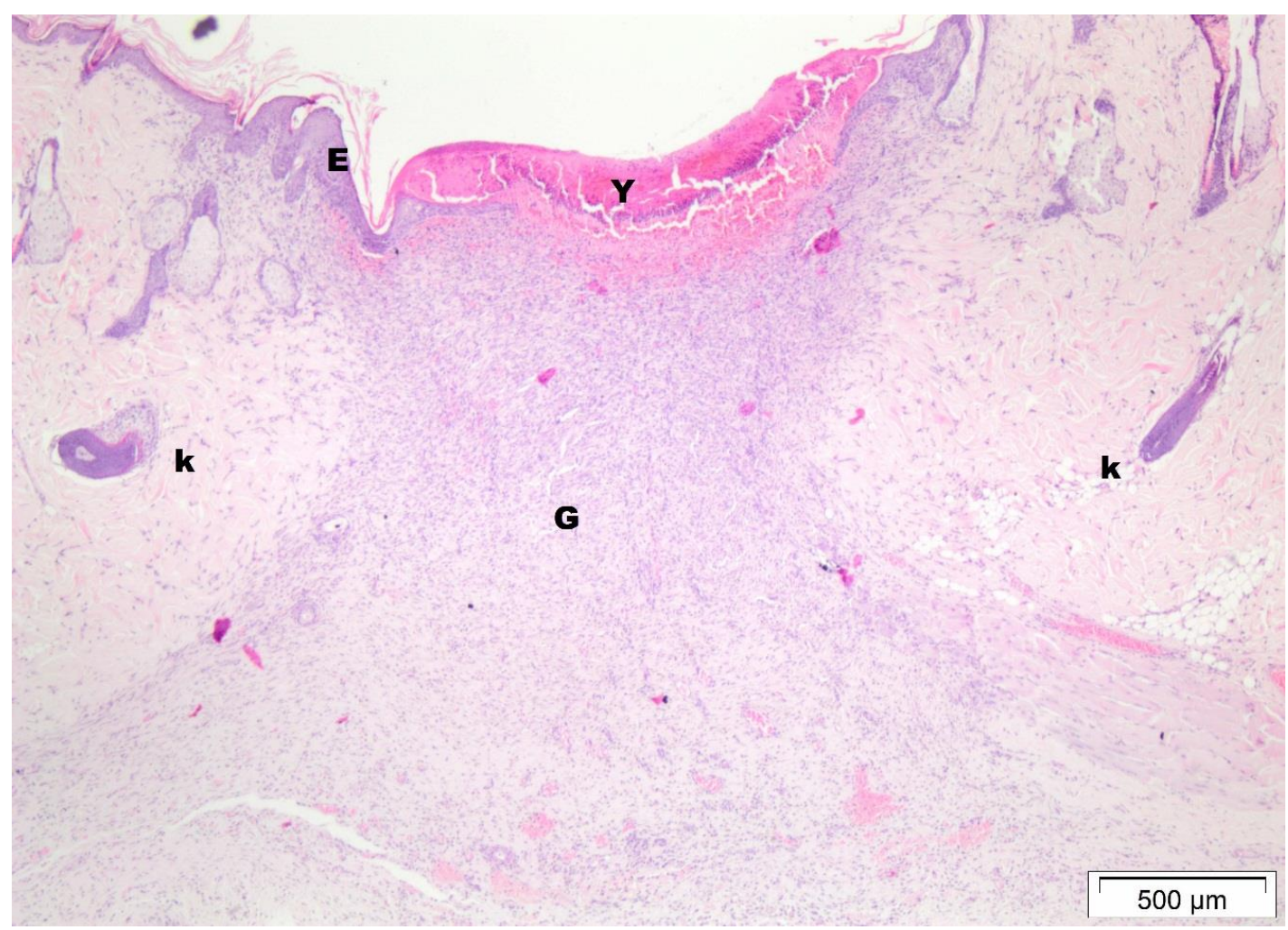

Figure 12. Control Group, Collagen Accumulation and Granulation Tissue Y: Very wide unhealed wound mouth. E: Epithelial, k:Collagen G:Granulation tissue

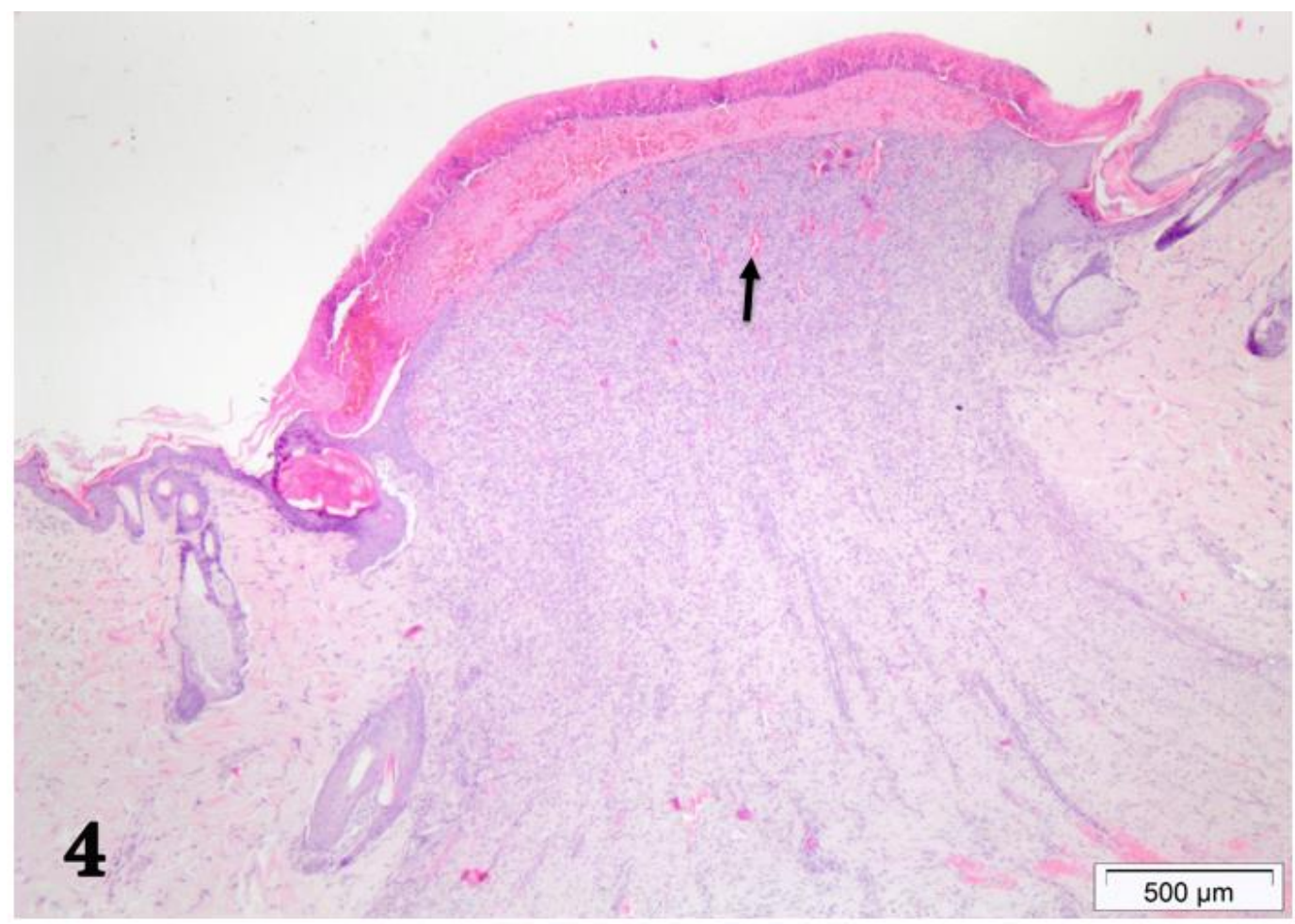

Figure 13. Control Group, Angiogenesis with a large and deep ulcer at the wound site Arrow: New vein formation perpendicular to epithelial surface 


\section{$\Lambda$ Macrothink}

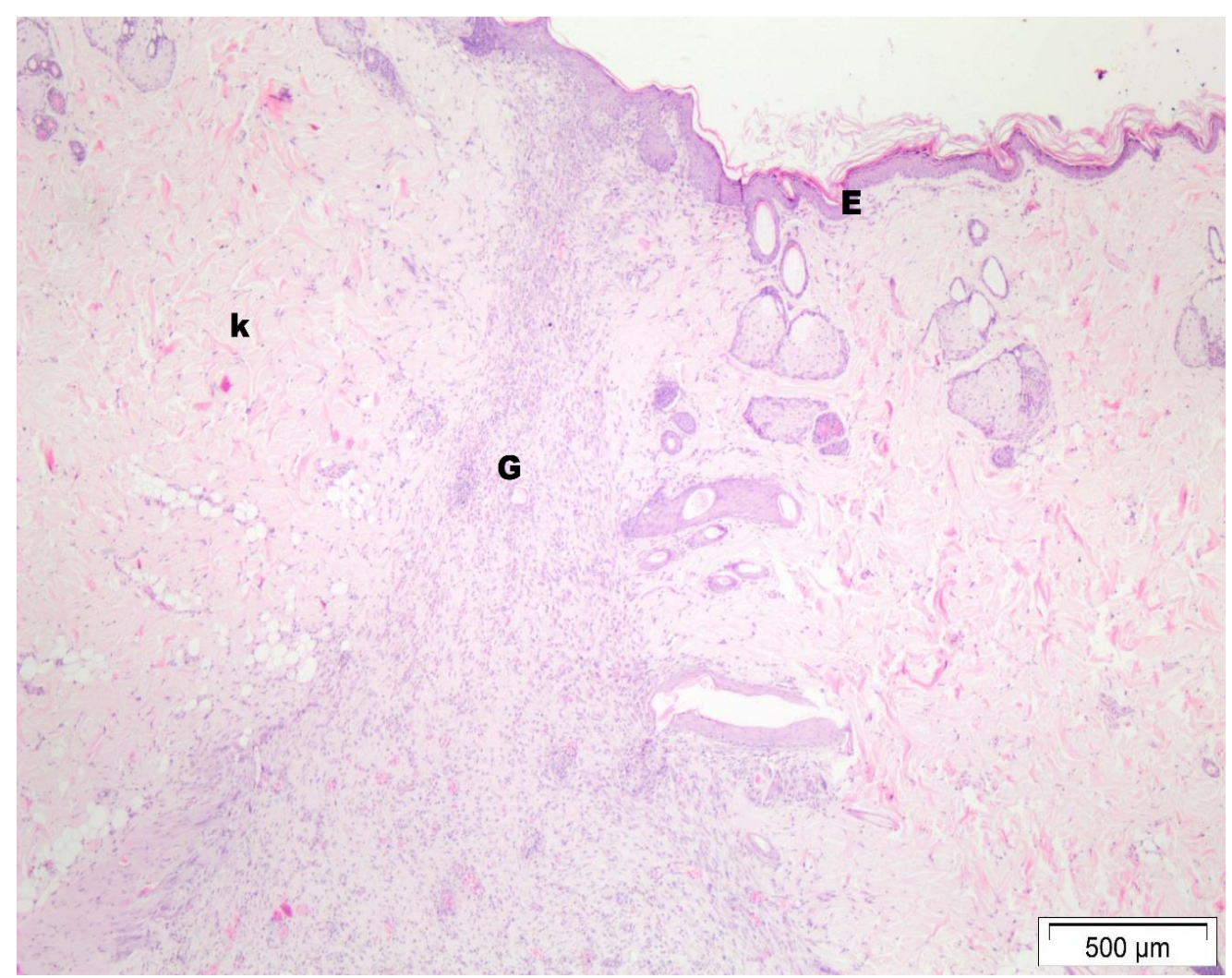

Figure 14. Study Group, Angiogenesis is quite reduced. E: Epithelial, k:Collagen G:Granulation tissue

\section{Discussion}

Wound and wound healing are important not only in terms of health and patient comfort, but also in terms of social and economic aspects (Woodfin et al., 2010 and El-Anwar et al., 2016). Wounds can occur in a wide range including small wounds in the skin and mouth, major wounds which are large and occur due to chronic (wounds due to diabetes mellitus, Chronic bed wounds etc.) diseases (Meshkini , 2015 and Mishra et al., 2013).

Wound healing is the result of trauma-induced cellular and biochemical events resulting in new tissue formation (Balabanov et al., 1996) and wound healing consists of three phases overlapping: hemostasis and inflammation, proliferation, maturation and remodeling (Ozerdem et al., 2001). Bleeding occurs after vascular injury inhemostasis phase. Vasoconstriction starts reflexively and platelets form the first occluder (Pablos et al., 1999). Subsequently, cytokines released from thrombocytes during the inflammatory phase attract neutrophils and fibroblasts to the wound. Within the first 24 hours, neutrophils dominate the wound. The primary role of the neutrophils is phagocytosis of bacteria and tissue debris (Takahashi et al., 199). It is also responsible for the release of various enzymes and cytokines. After 24-48 hours, the dominant cells in the wound are macrophages. They phagocyte cell debris. They modulate cell proliferation, matrix synthesis and angiogenesis by secreting cytokines such as TGF- $\beta$,IGF 1,EGF etc. (De Souza Franco et al., 2011). Finally, the maturation and remodeling phase is characterized by the rearrangement of the synthesized 
collagen. There is a balance between collagen production and destruction. Inflammatory cells gradually decrease (Leite \& Ramalho, 2008). In addition, the most important chemotactic factor for fibroblasts in the proliferation phase is PDGF. It is the period during which collagen is synthesized. Collagen synthesis peaks on days 5-7. It is the period of increased wound strain and angiogenesis occurs at this stage. Inflammatory cells gradually decrease after this process (Noble et al., 1989). In our findings, it was seen that the number of inflammatory cells decreased statistically significantly in the study (hot spring water) group on our 12th day, and that the production of collagen increased in a statistically significant amount. In the control group, on the 12th day, it was seen that the number of inflammatory cells was significantly high and the production of collagen was significantly low. The proportional values of inflammatory cell volume and collagen formation also showed that wound healing in the study group was better. Increased vascularization (angiogenesis) after wound formation and reduced vascularization during healing process and after recovery are expected. At the end of the 12th day there was a statistically significant reduction in vascularity in the study group relative to the control group. In the control group, on the 12th day, angiogenesis was high and vascularity was increased abundantly.

There are different mechanisms in wound healing, and one of them is epithelization (Nikulin \& Krylova, 1980). Epithelization: Closure of the defect with migration and proliferation of keratinocytes in the injuries of the skin or mucosa that are not full fold (Brandi et al., 2004 and Nikulin \& Krylova, 1980). It completes in less than 48 hours. Wound contraction: Recovery of wounds with loss of tissue, it is performed by myofibroblasts and is tried to be minimized by wound contraction. Contraction begins on day 5 , completes on day 39 . Wound contraction which may lead to more deformity and dysfunction: Approximately 80\% effective on closing and healing of open wounds.

Although there was no statistically significant difference between the groups in terms of re-epitalization in our findings, according to the control group, it was seen that the completed and mature epithelialization was numerically and proportionally higher in the study group. This finding supports statistically significant other parameters (eg, collagen production, inflammation, angiogenesis) which indicate that hot spring water is effective in wound healing.

Primer healing occurs when the sides of the wound are sutured with staples or tape. The result is minimal scarring.For the secondary healing, open wound is closed by contraction, granulation, epithelization and a larger scar tissue is formed (Yang et al., 2011; Ye et al., 2008 and Anghelina et al., 2004). If wound closure can not be achieved; chronic wound occurs.In the tertiary healing;excessive tissue necrosis and delayed wound healing for preventing development of infection at wounds in which there is foreign body or contamination, can be seen (Anjos-Afonso et al., 2004). Granulation should decrease or disappear at wound healing. In our findings, although there was no statistically significant difference between the groups in the study, it was seen that the granulation decreased and disappeared in a significant proportion. In the control group, granulation and maturation were continued. 
An ulcer also occurs with the appearance of the wound. The healing and disappear of ulcer can also show healing of wound (Fioravanti et al., 2011, El-Anwar et al., 2016). Although there was no statistically significant difference between groups in terms of ulcers in our findings, it appears that the ulcer has disappeared in the study group and in control group larger ulcers were numerically and proportionally more. All these findings and results in our pilot study, supports our observations and findings from the hot spring and supportsthe thought that hot spring water has a role and effectiveness in wound healing.

Although the wound and wound healing mechanisms have been described clearly; many pathophysiological processes underlying the healing process of the wound and the patient are still unknown (Sorg et al., 2017). However, in order to meet the needs of many unknowns; studies on the availability of water, plant, hot spring and similar paramedical solutions besides medical treatment have been carried out as well as in the past. Especially, the efficiency of CO2 gas in hot springs has been investigated (Irie et al., 2005, Fabry R et al., 2013, Fioravanti et al., 2011). Irie and colleagues have argued that topical CO2 bath in rats increases angiogenesis and $\mathrm{CO} 2$ enriched-water bath therapy may exhibit angiogenic therapy associated with neovascularization, such as transplantation of bone marrow mononuclear cells and VEGF gene therapy (Irie et al., 2005). Sonmez et al.; Showed that subcutaneous $\mathrm{CO} 2$ gas application increased vascular formation in the dorsal skin flap in rats, but did not affect perfusion as this increase would also increase the live flap area (Ozerdem et al., 2001). Although; hot spring, which is the subject of our work, was rich in various minerals and $\mathrm{CO} 2$ gas (table), we still did not know whatever beneficial effect of hot spring water on wound healing was due to CO2 gas (Irie et al., 2005, Fabry R et al., 2013, Sato et al.,2009,) or minerals in the water (Dandinoglu et al., 2016). Although wound healing mechanisms and cell functions have been described to a certain extent, many underlying pathophysiological processes are still unknown. Skin and wound healing is a complex process that is dependent on many cell types and mediators that interact in a highly complex temporal sequence (Sorg et al., 2017). As we did not know what will be the result in this pilot study; We generally want to investigate and evaluate the efficacy of this water in terms of the basic wound healing processes. When the situation is evaluated within the framework of the above information (Sorg et al., 2017) ; determination of the effect mechanism of the hot spring water and how these wounds were healed by hot spring water in these patients, who can not obtain results from medical treatment, can be realized with long working chains.

\section{Conclusion}

It has been found that the hot spring water that is the subject of study accelerates wound healing and improves the wounds in the subjects in a shorter time.

It was observed that wound of the patients who did not find any cure from medical treatment to their wounds due to various diseases and used this hot spring water with desperation, were recovered. The lack of recurrence in these recovered wounds (see photo 1-4, under follow-up for average 1.5-2 years), indicate that this water is effective in wound healing. The findings of our pilot study also support the idea that this water can be effective in wound healing and contribute to the healing of wounds. How to heal these wounds (photo) that can not get 
results from medical treatment but heals after spa therapy and with what effect and mechanism this water has contributed to healing should be investigated with wider concept and work.

\section{References}

Anghelina, M., Krishnan, P., Moldovan, L., \& Moldovan, N. I. (2004). Monocytes and macrophages form branched cell columns in matrigel: implications for a role in neovascularization. Stem Cells And Development, 13, 665-676.

https://doi.org/10.1089/scd.2004.13.665

Anjos-Afonso, F., Siapati, E. K., \& Bonnet, D. (2004). In vivo contribution of murine mesenchymal stem cells into multiple cell-types under minimal damage conditions. Journal Of Cell Science, 117, 5655-5664. https://doi.org/10.1242/jcs.01488

Balabanov, R., Washington, R., Wagnerova, J., \& Dore-Duffy, P. (1996). CNS microvascular pericytes express macrophage-like function, cell surface integrin aM and macrophage marker ED-2. Microvascular Research, 52, 127-142. https://doi.org/10.1006/mvre.1996.0049

Brandi, C., D’Aniello, C., Grimaldi, L., Caiazzo, E., \& Stanghellini E. (2004). Carbon dioxide therapy: effects on skin irregularity and its use as a complement to liposuction. Aesthetic Plastic Surgery, 28, 222-225. https://doi.org/10.1007/s00266-004-2068-z

Dandinoglu, T., Dandin, O., Ergin, T., Tihan, D., Akpak, Y. K., Aydın, O. U., \& Teomete, U. (2016). Can balneotherapy improve the bowel motility in chronically constipated middle-aged and elderly patients?. International Journal of Biometeorology.

http://doi: 10.1007/s00484-016-1295-8.

DeSouzaFranco, E., de Aquino, C. M., ..., \& de SouzaMaia, M. B. (2012). Effect of a Semisolid Formulation of Linum usitatissimum L. (Linseed) Oil on the Repair of Skin Wounds. Evidence-Based Complementary and Alternative Medicine.

http:// doi: 10.1155/2012/270752.

Diji, A. (1959). Local vasodilator action of carbon dioxide on blood vessels of the hand. Journal of Applied Physiology, 14, 414-416.

El-Anwar, M. W., Abdelmonem, S., Abdelsameea, A.A., AlShawadfy, M., \& El-Kashishy K . (2016). The Effect of Propolis in Healing Injured Nasal Mucosa: An Experimental Study. International Archives of Otorhinolaryngology, 20, 222-225.

https://doi.org/10.1055/s-0036-1579664

Fabry, R., Dubost, J. J., ..., \& Baguet, J. C. (1995). Thermal treatment in arterial diseases: an expensive placebo or an effective therapy?. Therapie, 50, 113-122.

Fioravanti, A., Cantarini, L., Guidelli, G. M., \& Galeazzi, M. (2011). Mechanisms of action of spa therapies in rheumatic diseases: what scientific evidence is there? Rheumatology international, 31, 1-8. https://doi.org/10.1007/s00296-010-1628-6

Irie, H., Tatsumi, T, ..., \& Matsubara, H. (2005). Carbon dioxide rich water bathing enhances 
collateral blood flow in ischemic hindlimb via mobilization of endothelial progenitor cells and activation of NO cGMP system. Circulation, 111, 1523-1529.

https://doi.org/10.1161/01.CIR.0000159329.40098.66

Leite, F. R, \& Ramalho, L. T. (2008). Bone regeneration after demineralized bone matrix and castor oil (Ricinus communis) polyurethane implantation. Journal of Applied Oral Science, 16, 122-126. https://doi.org/10.1590/S1678-77572008000200008

Meshkini, A. Acetone Extract of Almond Hulls Provides Protection against Oxidative Damage and Membrane Protein Degradation. J AcupunctMeridianStud. (2016). Journal Of Acupuncture and Meridian Studies, 9, 134-142. https://doi.org/10.1016/j.jams.2015.10.001

Mishra, S., Triptahi, V., .., \& Shukla, R. K. (2013). Wound induced transcriptional regulation of benzylisoquinoline pathway and characterization of wound inducible PsWRKY transcription factor from Papaver somniferum. Public Library of Science One, 8, e52784. http://doi: 10. 1371/journal.pone.0052784.

Nayak, B. S., \& Pinto Pereira, L. M. (2006). Catharantusroseus extract has wound healing activity in Sprague Dawley rats. BMC Complementary and Alternative Medicine, 21, 41. https://doi.org/10.1186/1472-6882-6-41

Nikulin, A. A., \& Krylova, E. A. (1980). Comparative evaluation of the treatment of radiation skin injuries with oxycort ointment and Peruvian balsam. Farmakologiia i Toksikologiia, 43, 97-100.

Noble, T. A, Carr, D. S., \& Gonzalez, M. F. (1989). Use of a trypsin, Peru balsam, and castor oil spray on the oral mucosa: case report and review of the literature. Pharmacotherapy, 9, 386-8. https://doi.org/10.1002/j.1875-9114.1989.tb04154.x

Ozerdem, U., Grako, K.A., ..., \& Stallcup, W. B. (2001). NG2 proteoglycan is expressed exclusively by mural cells during vascular morphogenesis. Developmental Dynamics, 222, 218-27. https://doi.org/10.1002/dvdy.1200

Pablos, J. L., Amara, A., ..., \& Arenzana-Seisdedos, F. (1999). Stromal-cell derived factor is expressed by dendritic cells and endothelium in human skin. The American Journal of Pathology, 155, 1577-1586. https://doi.org/10.1016/S0002-9440(10)65474-0

Petersen, H., Tavakoli, F., ..., \& Miller, R. J. (2016). ;Comparativestudy of woundhealing in rat skin following incision with a novelpicosecondinfraredlaser (PIRL) and different surgical modalities. Lasers in Surgery and Medicine, 48, 385- 391. https://doi.org/10.1002/lsm.22498

Sato, M., Kanikowska, D., ..., \& Sugenoya, J. (2009). Effects of immersion in water containing high concentrations of $\mathrm{CO} 2$ ( $\mathrm{CO} 2$-water) at thermoneutral on thermoregulation and heart rate variability in humans. International Journal of Biometeorology, 53, 25-30. https://doi.org/10.1007/s00484-008-0188-X

Sorg, H., Tilkorn, D. J., ..., \& Mirastschijski, U. (2017). Skin Wound Healing: An Update on the Current Knowledge and Concepts. European Surgical Research, 58, 81- 94.

https://doi.org/10.1159/000454919 


\section{Macrothink}

Journal of Biology and Life Science ISSN 2157-6076 2017, Vol. 8, No. 2

Takahashi, T., Kalka, C., ..., \& Asahara, T. Ischemia- and cytokine-induced mobilization of bone marrow-derived endothelial progenitor cells for neovascularization. (1999). Nature Medicine, 5, 434-438. https://doi.org/10.1038/8462

Voisin, M. B, Pröbstl, D., \& Nourshargh, S. (2010). Venular basement membranes ubiquitously express matrix protein low-expression regions: characterization in multiple tissues and remodeling during inflammation. The American Journal of Pathology, 176, 482-495. https://doi.org/10.2353/ajpath.2010.090510

Woodfin, A., Voisin, M. B., \& Nourshargh, S. (2010) Recent developments and complexities in neutrophil transmigration. Current Opinion in Hematology, 17, 9-17.

https://doi.org/10.1097/MOH.0b013e3283333930

Yang, H. S., Shin, J., ..., \& Kim, B. S. (2011). Enhanced skin wound healing by a sustained release of growth factors contained in platelet-rich plasma. Experimental \& Molecular Medicine, 43, 622-629. https://doi.org/10.3858/emm.2011.43.11.070

Ye, C., Bai, L., ..., \& Jiang, Z. L. (2008). Shear stress and vascular smooth muscle cells promote endothelial differentiation of endothelial progenitor cells via activation of Akt. Clinical Biomechanics, 23, 118-124. https://doi.org/10.1016/j.clinbiomech.2007.08.018

\section{Copyright Disclaimer}

Copyright for this article is retained by the author(s), with first publication rights granted to the journal.

This is an open-access article distributed under the terms and conditions of the Creative Commons Attribution license (http://creativecommons.org/licenses/by/3.0/). 